\title{
Seroprevalence and risk factors of brucellosis in abattoir workers at Debre Zeit and Modjo export abattoir, Central Ethiopia
}

\author{
Amanuel Tsegay ${ }^{1}$, Getachew Tuli ${ }^{2}$, Tesfu Kassa ${ }^{1}$ and Nigatu Kebede ${ }^{1 *}$
}

\begin{abstract}
Background: Brucellosis is one of the major zoonoses globally with great veterinary and public health importance, particularly in developing countries where people are having frequent contact with livestock and animal products. This cross sectional study was carried out from November 2013 to May 2014 to determine the seroprevalence and assess the potential risk factors of brucellosis in abattoir workers of five export abattoirs at Debre Ziet and Modjo, Central Ethiopia.
\end{abstract}

Methods: Serology and structured questionnaire were the methods used. In this study, 156 abattoir workers participated in the questionnaire survey and among them, 149 agreed for blood sample collection. Rose Bengal Plate Test and Complement Fixation Test were conducted using sera samples at serology laboratory of the National Animal Health Diagnostic and Investigation Center. Data collection sheets were used to gather information on possible risk factors believed to influence the spread of Brucella infection in abattoir workers such as sex, age, marital status, duration on job, types of work, educational level, etc. and further information obtained include knowledge of brucellosis and other zoonotic diseases infection, symptoms of the disease, milk and meat consumption habits and work related risk factors. Chi-square and Fisher's exact tests were used for data analysis.

Results: The overall seroprevalence of brucellosis in abattoir workers was found to be 4.7 and $1.3 \%$ using Rose Bengal plate test and Compliment fixation test, respectively. Based on the questionnaire survey, $66(44.2 \%)$ and 85 (53.21\%) of abattoir workers were aware of brucellosis and other zoonotic diseases, and 29 (18.6\%) and 21 (13.5\%) were using gloves and cover their mouth while slaughtering, respectively.

Conclusion: Brucellosis in abattoir workers could be prevented by using protective closing and measures. Concerned body should educate occupationally exposed groups and the general public regarding e prevention and control of brucellosis and other zoonotic diseases.

Keywords: Abattoirs workers, Brucellosis, CFT, RBPT, Seroprevalence, Ethiopia

\section{Background}

Nowadays, our world has been threatened by numerous emerging and re-emerging pathogenic diseases; these diseases are seriously affecting the well being of human, animal health, and animal production [1]. Most of them are zoonotic diseases and have great veterinary and public health impact, particularly in developing countries where people are having daily frequent contact with

\footnotetext{
* Correspondence: nigatukebede@yahoo.com; nigatu.kebede@aau.edu.et 'Akillu Lemma Institute of Pathobiology (ALIPB), Addis Ababa University (AAU), P. O. Box: 150480, Addis Ababa, Ethiopia

Full list of author information is available at the end of the article
}

livestock and animal products. Brucellosis is one of them, and it causes significant economic losses due to abortion, lower milk production and reduced fertility in livestock and serious health problem in human beings [2]. It is one of the most widespread and the second most important global zoonoses after rabies [3-5]. Brucellosis is endemic in many parts of the world including Latin America, the Middle East, western Asia, part of Mediterranean regions and Africa [6]. Ever increasing international trade of animal and animal products, movement of people, and urbanization significantly 
contributed for the transmission of the diseases between animals and humans [7].

Brucellosis is more prevalent in developing countries and considered to be a serious health problem due to lack of effective public health measures, domestic animal health programs, and appropriate diagnostic facilities. Furthermore, the situation is also worsened by the resemblance of the disease with other diseases leading to misdiagnosis and under-reporting [8].

Brucellosis is an infectious bacterial disease caused by members of the genus Brucella and characterized as small, facultative, gram negative, non-motile, non-spore forming and rod shaped (coccobacilli) bacteria $[9,10]$. Human beings are susceptible to infection with $B$. abortus, $B$. melitensis, $B$. suis biovars $1-4$, and rarely $B$. canis; however, $B$. melitensis causes serious infection and is responsible for the most of worldwide morbidity [11]. Brucellosis in humans is a systemic disease characterized by acute or insidious onset of continued, intermittent, undulent or irregular fever of variable duration, headache, profuse sweating, chills, weakness, generalized aching, and joint pain [12].

From public health point of view, brucellosis is considered to be an occupational disease that mainly affects abattoir workers, farm laborer, animal keepers, butchers, veterinarians and laboratory workers [13]. However, abattoir workers are more prone to acquire brucellosis than other occupations, because they are over exposed to carcasses, viscera, and organs of infected animals [8]. Mukhtar and Kokab, [8] and Karimi et al. [14] reported a prevalence of brucellosis among slaughter house workers, $21.7 \%$ in Pakistan and 35.7\% in Saudi Arabia, respectively.

In Ethiopia, a number of zoonotic diseases are known to have public health and economic importance both in humans and animals. The present study has particularly given emphasise to brucellosis because of the high morbidity and its significance to the public health and the economy of the country; brucellosis is of high national priority. Like other developing countries, brucellosis has not been brought under control in Ethiopia in livestock, which might be due to mismanagement on animal quarantine, trans-boundary animal movement, a lack of eradication and vaccination program, and that of awareness of the disease among pastoralist, farmers and general public [15]. Very few studies were carried out to determine seroprevalence of brucellosis in humans, particularly occupational exposed group in Ethiopia. Some of the previous studies indicated that there is a prevalence of brucellosis in pastoralist, farmers and occupational exposed groups. Tolosa et al. [16], Kassahun et al. [17], Hailemelekot et al. [18], Kassahun et al. [19] and Haileselassie et al. [20] reported prevalence of human brucellosis of 2.4, 5.3, 3.8, 4.8 and $1.2 \%$ in different parts of the country, respectively. However, the prevalence of human brucellosis in Ethiopia is not well documented. In addition, with the exception of few studies, awareness level of brucellosis and its public health significance among occupational exposed group is almost unknown. Hence, this study was aimed at estimating the seroprevalence of brucellosis in abattoir workers and assesses the factors predisposing abattoir workers to brucellosis in selected export abattoirs at Debre Zeit and Modjo, Central Ethiopia.

\section{Methods \\ Study areas}

There are seven functional export abattoirs found in Ethiopia, and five of them are located in the cities of Debre Zeit and Modjo, Central Ethiopia. This investigative work has been done in five export abattoirs located at Debre Zeit and Modjo due to their proximity to Addis Ababa and Sebeta where National Animal Health Diagnostic and Investigation Center is located. Debre Zeit is approximately $47 \mathrm{~km}$ south east of Addis Ababa, and found at $9^{\circ} \mathrm{N}$ and $40^{\circ} \mathrm{E}$ with an altitude of $1880 \mathrm{~m}$ above sea level. It has an annual rainfall of $1151.6 \mathrm{~mm}$, and its mean annual minimum and maximum temperature is $8.5^{\circ} \mathrm{C}$ and $30.7^{\circ} \mathrm{C}$, respectively, and the mean humidity is $61.3 \%$. Modjo is about $77 \mathrm{~km}$ south east of Addis Ababa located at $8^{\circ} 35^{\prime} \mathrm{N}$ and $39^{\circ} 10^{\prime} \mathrm{E}$ at an altitude of 1777 masl. The average maximum and minimum temperature is 28 and $18^{\circ} \mathrm{C}$ [21].

\section{Study design}

A cross sectional study was employed from November 2013 to May 2014 to determine the seroprevalence of brucellosis and assess the associated risk factors to Brucella seropositivity and to determine the awareness level of brucellosis among export abattoirs workers.

\section{Sample size and study subjects}

The sample size was calculated using the method recommended by Thrusfield, [22]. The sample size for abattoir workers were determined based on the recent seroprevalence studies of brucellosis in Ethiopia. According to Negash et al. [1] and Kassahun et al. [19], a prevalence of $4.8 \%$ was considered to determine sample size. Accordingly, the minimum samples 70 with $95 \%$ confidence interval and 5\% margin of error. However, to increase precision level the numbers of abattoirs workers to be examined were increased to 156 .

The formula for calculating sample size:-

$$
n=Z_{\frac{a}{2}}{ }^{2} \frac{P(1-P)}{d^{2}}
$$

Where; 
$\mathrm{n}=$ the minimum sample size required for very large population

$\mathrm{Z}=$ the critical value for a given confidence interval

$\mathrm{P}=$ expected proportion of the event to be studied

$\mathrm{d}=$ margin of error (the margin of error is 0.05 )

Study subjects were assigned proportionally to each abattoir, based on the number of workers that particular abattoir employed. After getting the desired sample size for each abattoir, stratified sampling techniques were employed to determine sampling population in each category. After getting the job description of workers of export abattoirs, each worker was allocated to his/her specific strata based on his/her type of job into five classes such as: veterinarian, slaughterer, loader, cleaner and animal keeper. Then sample was drawn from each strata proportionally using systematic random sampling to get the final sample size.

Abattoir workers of the five export abattoirs who have direct contact with live, carcasses, organs and viscera of animals were study population. One hundred fifty six employees were selected as a study subject and interviewed by the principal investigator; however, blood samples were taken only from 149 respondents who were voluntary to give blood samples.

\section{Eligibility criteria \\ Inclusion criteria}

Employees of the five export abattoirs who have direct contact with live and carcasses of ruminants; workers who can understand questionnaire and sign the informed consent and the age above 18 year old.

\section{Exclusion criteria}

Temporary workers; workers not voluntary to participate in the study and individuals in the administrative and managerial posts.

\section{Questionnaire survey}

A structured questionnaire was used to gather information on socio-demographic characters of the respondents such as: sex, age, marital status, duration on job, types of work and etc.; and further information obtained include level of awareness of brucellosis and other zoonotic diseases infection, symptoms of the disease, milk and meat consumption habits and work related risk factors. The questionnaire was translated to local language and administered by the principal investigator in order to minimize bias by the interviewer.

\section{Blood sample collection}

Approximately 3-5 $\mathrm{ml}$ of venous blood was drawn from each respondents using plain vacutainer tube (BD vacutate, UK), syringe and needles using aseptic techniques. Each vacutainer tube was marked with a permanent marker recording the case number of the respective study subject and the name of the abattoirs. The blood samples were placed at an inclined position and allowed to clot for $1-2 \mathrm{~h}$ at room temperature in order to get clear serum and to minimize hemolysis of blood. Then stored overnight horizontally at $4{ }^{\circ} \mathrm{C}$, the serum was separated from the clot by centrifugation at $2500 \mathrm{rpm}$ for $10 \mathrm{~min}$ at room temperature. Finally, the serum was transferred to a labeled vial and stored in deep freezer $\left(-20^{\circ} \mathrm{C}\right)$ until further test was done. Blood samples were taken by qualified medical personnel.

\section{Serological tests}

Two types of serological tests were employed as a screening and confirmatory test for the detection of Brucella antibody in human serum, the Rose Bengal plate Test (RBPT) and Compliment Fixation Test (CFT), respectively. Both serological tests were done at the $\mathrm{Na}$ tional Animal Health Dagnostic and Investigation Center (NAHDIC).

\section{Rose Bengal plate tests}

RBPT was used as a screening test for the serum samples collected for the presence of Brucella agglutinins. The test was conducted as per recommended procedure $[23,24]$. Equal volumes of test serum and Brucella abortus antigen Strain 99 (LD, UK) $(30 \mu \mathrm{l})$ were placed alongside in a plate and then mixed thoroughly with tooth pick then rocked for $4 \mathrm{~min}$ with hands. Then the results were interpreted according to the presence and degree of agglutination. Samples with no agglutination (0) were recorded as negative while those with,+++ , and +++ were recorded as positive.

\section{Complement fixation tests}

All sera tested positive using RBPT were further confirmed using CFT. The complement system consists of series of proteins that, if triggered by an antigen antibody complex, react in a sequential manner to cause cell lysis. The test has two steps. The first step is antigen, test serum and complement are mixed and incubated. The second step is an indicator system which consists of sheep red blood cells (SRBC) and amboceptor that sensitizes red blood cells to the action of the complements. If the test serum contains antibodies to Brucella, an antigen-antibody complex is formed; the complement is used up and no lysis of SRBC occurs. If the test serum does not contain Brucella antibodies (negative reaction), the complement will not be fixed and lysis of SRBC would occur [23].

\section{Data collection and data analysis techniques}

Results from serological tests, questionnaires and data collection sheets were coded and stored in EpiData 
version 3.1, and then exported to STATA (Stata Corp, Texas, USA) version 11.0 for data analysis. Positive samples confirmed using CFT were considered as true seropositive and taken for further data analyses. The test agreement between RBPT and CFT was analyzed using Kappa statistics. Categorical data were expressed in percentage, and seroprevalence was calculated by dividing the number of positive sera samples by the total samples examined. Odds ratio, 95\% confidence interval, and Chisquare and Fisher's exact tests were computed to see the degree of association of the risk factors with Brucella seropositivity. For all analysis, a $p$ value $<0.05$ was taken as significant. In the present study five export abattoirs have participated, namely, Hashim, Elfora, Luna, Organic and Modjo export abattoirs. In order to insure confidentiality of the participating abattoirs, code numbers were used.

\section{Results}

Of the 149 human sera samples screened with RBPT, 7 $(4.70 \%)$ were found positive. Samples screened positive for RBP further confirmed with CFT where 2 (1.34\%) were confirmed positive. Relatively high Brucella seropositivity was observed in female respondents than in male, and within the age group of 21-30 years old than other age groups. On residential background, high seroprevalence was recorded in workers with rural background than urban (Table 1). Only Moderate agreement $[$ Kappa $=0.4326]$ was observed between RBPT and CFT for the detection of Brucella antibody in abattoir workers. High Brucella seropositivity was found among respondents who work from 6 to 10 years on job, primary school background and cleaner (Table 2).

Questionnaire survey was conducted on 156 abattoir workers about their knowledge on brucellosis and other zoonotic diseases. Of these, $125(80.1 \%)$ were men whilst 31 (19.9\%) were women. The overall awareness level of abattoir workers toward brucellosis and other zoonotic diseases was $69(44.2 \%)$ and $83(53.2 \%)$, respectively (Table 3). However, there was no statistically significant difference in the knowledge about brucellosis and other zoonotic diseases among gender, age, marital status, residential background and duration on job $(p>0.05)$.

Knowledge of brucellosis and other zoonotic diseases of post secondary workers was $15(68.2 \%)$ and 19 (86.5\%), respectively, while that of veterinarian was 12 (100\%). Statistically significant difference was observed in the knowledge about brucellosis and other zoonotic diseases of those post secondary school background with the other level of education, respectively $(p=0.010$ and $p=0.001)$. Similarly, statistically significant difference was observed in the knowledge about the diseases by that of the veterinarians than other worker classes $(p=$ $0.001)$ and $(p=0.009)$ (Table 4).

Regarding questions on predisposing factors for brucellosis, out of 156 respondents $29(18.6 \%)$ and 21 (13.4\%) replied using gloves and cover their mouth during slaughtering and eviscerating process, respectively.

Table 1 Demographic characterstics and seroprevalence of brucellosis in abattoir workers of Debre Zeit and Modjo export abattoirs $(N=149)$

\begin{tabular}{|c|c|c|c|c|c|}
\hline Category & $N$ & $\begin{array}{l}\text { RBPT positive } \\
N(\%)\end{array}$ & $\begin{array}{l}\text { CFT positive } \\
N(\%)\end{array}$ & $\begin{array}{l}95 \% \mathrm{Cl} \\
\text { for CFT }\end{array}$ & $\begin{array}{l}\text { Fisher's exact } \\
P \text {-value }\end{array}$ \\
\hline \multicolumn{6}{|l|}{ Sex } \\
\hline Male & 122 & $5(4.10)$ & $1(0.82)$ & $0.02-4.48$ & \multirow[t]{2}{*}{0.331} \\
\hline Female & 27 & $2(7.41)$ & $1(3.70)$ & 0.09-18.97 & \\
\hline \multicolumn{6}{|l|}{ Age (in years) } \\
\hline$<=20$ & 19 & $1(5.26)$ & - & & \\
\hline $21-30$ & 75 & $5(6.49)$ & $2(2.6)$ & \multirow[t]{4}{*}{$0.32-9.07$} & \multirow[t]{4}{*}{1} \\
\hline $31-40$ & 35 & - & - & & \\
\hline $41-50$ & 9 & $1(11.11)$ & - & & \\
\hline$>50$ & 9 & - & - & & \\
\hline \multicolumn{6}{|l|}{ Marital status } \\
\hline Single & 57 & $5(8.77)$ & $1(1.75)$ & $0.04-9.39$ & \multirow[t]{3}{*}{1} \\
\hline Married & 89 & $2(2.25)$ & $1(1.12)$ & $0.03-6.10$ & \\
\hline Divorced/widowed & 3 & - & - & & \\
\hline \multicolumn{6}{|l|}{ Background } \\
\hline Urban & 120 & $5(4.17)$ & $1(0.83)$ & $0.02-4.56$ & \multirow[t]{3}{*}{0.352} \\
\hline Rural & 29 & $2(6.90)$ & $1(3.45)$ & $0.09-17.46$ & \\
\hline Total & 149 & $7(4.70)$ & $2(1.34)$ & $0.16-4.76$ & \\
\hline
\end{tabular}


Table 2 Seroprevalence of brucellosis among Debre Zeit and Modjo abattoirs workers by years on job, level of education, types of job and name of abattoir $(N=149)$

\begin{tabular}{|c|c|c|c|c|c|}
\hline Category & $N$ & $\begin{array}{l}\text { RBPT positive } \\
N(\%)\end{array}$ & $\begin{array}{l}\text { CFT positive } \\
\text { no (\%) }\end{array}$ & $\begin{array}{l}95 \% \mathrm{Cl} \\
\text { for CFT }\end{array}$ & $\begin{array}{l}\text { Fisher's exact } \\
P \text {-value }\end{array}$ \\
\hline \multicolumn{6}{|l|}{ Years on job } \\
\hline$<1$ & 19 & $1(5.26)$ & - & & \\
\hline $1-5$ & 82 & $3(3.66)$ & - & & \\
\hline $6-10$ & 33 & $3(9.09)$ & $2(6.06)$ & $0.74-20.23$ & 0.173 \\
\hline $11-15$ & 11 & - & - & & \\
\hline$>15$ & 4 & - & - & & \\
\hline \multicolumn{6}{|l|}{ Level of education } \\
\hline Illiterate & 13 & $1(7.69)$ & - & & \\
\hline Primary & 54 & $3(5.56)$ & $2(3.70)$ & $0.45-12.75$ & 0.546 \\
\hline Secondary & 60 & $3(5.00)$ & - & & \\
\hline Post secondary & 22 & - & - & & \\
\hline \multicolumn{6}{|l|}{ Types of job } \\
\hline Animal keepers & 23 & - & - & & \\
\hline Slaughterers & 60 & $1(1.67)$ & - & & \\
\hline Loaders & 31 & $2(6.45)$ & $1(3.23)$ & $0.08-16.70$ & 0.355 \\
\hline Veterinarian & 12 & - & - & & \\
\hline Cleaners & 23 & $4(17.39)$ & $1(4.35)$ & $0.11-21.95$ & \\
\hline \multicolumn{6}{|l|}{ Name of abattoirs } \\
\hline Abattoir 1 & 30 & - & - & & \\
\hline Abattoir 2 & 27 & $1(3.70)$ & $1(3.70)$ & 0.09-18.97 & \\
\hline Abattoir 3 & 30 & $1(3.33)$ & $1(3.33)$ & $0.08-17.21$ & 0.342 \\
\hline Abattoir 4 & 31 & $5(16.13)$ & - & & \\
\hline Abattoir 5 & 31 & - & - & & \\
\hline
\end{tabular}

In addition, 109 (69.9\%), 107 (68.6\%) and $76(48.7 \%)$ of the respondents consumed raw dairy products and meat, and accidentally cut during slaughtering and eviscerating, respectively (Table 5).

\section{Discussion}

The present investigation found an indication for prevalence of brucellosis and the relatively low level of awareness of export abattoir workers about brucellosis and other zoonotic diseases. Overall, 149 abattoir workers sera samples were examined for the presence of brucellosis. Of the total examined, prevalence of brucellosis using RBPT and CFT was found to be 4.7 and $1.3 \%$, respectively. Observed differences between the two tests might be due to cross reaction of Brucella with other bacteria which share similar epitopes. In Ethiopia, very few studies have been conducted to determine prevalence of brucellosis in humans particularly in abattoir workers. The few similar studies in the literature, particularly the work done in association with occupational groups as in the present study, reported prevalence of 16 (4.8\%) and 3 (1.2\%) brucellosis, in Addis Ababa and
Western Tigray slaughter houses, respectively $[19,20]$. Compared to the present study, however, the relatively higher seroprevalence of brucellosis observed by Kassahun et al. [19] might be attributed to the the large sample size involved and/or the different confirmatory tests used by the two studies, CFT versus 2-mercaptoethanol test (MET). Rather, very high Brucella infection was reported in abattoir workers in other countries, Agasthya et al. [25] and Mukhtar and Kokab [8] reported prevalence of 97 (19.69\%) and 78 (21.7\%) among slaughter house workers in India and Pakistan, respectively. This might be correlated to low prevalence of small ruminant brucellosis reported in these abattoirs [26]. Since seropositivity of brucellosis in human is largely affected by the presence of the disease among domestic animals [11].

Concerning knowledge of brucellosis and other zoonotic diseases, questionnaire based data were collected from the selected five export abattoir workers.. The overall awareness level of brucellosis and other zoonotic diseases among export abattoir workers were found to be relatively low. In addition, most of the workers do not wear protective clothing while slaughtering and 
Table 3 Awareness level of abattoir workers on brucellosis and other zoonotic diseases in Debre Zeit and Modjo export abattoirs $(N=156)$

\begin{tabular}{|c|c|c|c|c|c|c|c|}
\hline Category & $N$ & $\begin{array}{l}\text { Brucellosis } \\
\text { (yes) N (\%) }\end{array}$ & $x^{2}$ & $P$-Value & $\begin{array}{l}\text { Zoonosis } \\
\text { (yes) N (\%) }\end{array}$ & $x^{2}$ & $P$-Value \\
\hline \multicolumn{8}{|l|}{ Sex } \\
\hline Male & 125 & $55(44.00)$ & 0.013 & 0.907 & $68(54.40)$ & & \\
\hline Female & 31 & $14(54.84)$ & & & $15(48.39)$ & 0.361 & 0.548 \\
\hline \multicolumn{8}{|l|}{ Age (in years) } \\
\hline$<=20$ & 21 & $3(14.29)^{\mathrm{a} 1}$ & & & $7(33.33)$ & & \\
\hline $21-30$ & 80 & $35(43.75)^{a}$ & 12.075 & 0.017 & $44(55.00)$ & & \\
\hline $31-40$ & 37 & $19(51.35)^{b}$ & & & 19 (51.35) & 6.323 & 0.176 \\
\hline $41-50$ & 9 & $6(66.67)^{b}$ & & & $6(66.67)$ & & \\
\hline$>50$ & 9 & $6(66.67)^{b}$ & & & $7(77.78)$ & & \\
\hline \multicolumn{8}{|l|}{ Marital Status } \\
\hline Single & 60 & $22(36.67)$ & & & $32(53.33)$ & & \\
\hline Married & 92 & $43(46.74)$ & 6.670 & 0.036 & $48(52.17)$ & 0.803 & 0.669 \\
\hline Divorced/Widowed & 4 & $4(100)$ & & & $3(75.00)$ & & \\
\hline \multicolumn{8}{|l|}{ Back Ground } \\
\hline Urban & 125 & $58(46.40)$ & & & $68(54.40)$ & & \\
\hline Rural & 31 & $11(35.48)$ & 1.200 & 0.273 & 15 (48.39) & 0.361 & 0.548 \\
\hline \multicolumn{8}{|l|}{ Years On Job } \\
\hline$<1$ & 19 & $5(26.32)$ & & & $9(47.37)$ & & \\
\hline $1-5$ & 86 & $35(40.70)$ & 7.626 & 0.106 & $45(52.33)$ & 1.193 & 0.879 \\
\hline $6-10$ & 35 & $18(51.43)$ & & & $19(54.29)$ & & \\
\hline $11-15$ & 12 & $8(66.67)$ & & & $7(58.33)$ & & \\
\hline$>16$ & 4 & $3(75.00)$ & & & $3(75.00)$ & & \\
\hline Total & 156 & $69(44.23)$ & & & $83(53.21)$ & & \\
\hline
\end{tabular}

${ }^{1}$ Within a variable, values in the same column with different letters differ significantly

eviscerating animals and considerable portion of abattoir workers consumed raw meat and dairy products. Similar finding was also reported by Tuli, [27] among export and municipal abattoir workers in Debre Zeit. This might be attributed to their educational status, since most of the workers were illiterate or primary education background. Additionally, it could also be due to a lack of awareness creation program about zoonotic diseases among abattoir workers.

Data analysis has been done using Chi-square test and $p$-value to see if there were associations between different categories of workers and awareness level of brucellosis and other zoonotic diseases. Statistically significant differences were observed in the level of knowledge of brucellosis and other zoonotic diseases of workers with post secondary school background and veterinarian with their respective classes. The high level of awareness of brucellosis and other zoonotic diseases among veterinarian and those post secondary school background were as expected. Because veterinarians and workers with post secondary education background have considerable theoretical knowledge about the diseases during their professional training and also have good amount of practical knowledge through their experiences. Similarly, statistically significant difference was also observed among different age groups of the respondents toward awareness of brucellosis. This could be due to the age of the workers whereby older people be more aware of the disease than the young ones, through their lifelong experiences. On the other hand, statistically significance difference was not observed among other categories of abattoir workers with regard to knowledge of brucellosis and other zoonotic diseases, despite considerable variation in their knowledge about the diseases.

Generally, a lack of sufficient knowledge of brucellosis and other zoonotic diseases, unprotective working conditions, regular exposure from aerosol and contact through cuts and abrasion to infected materials such as carcasses, viscera, organs, blood and urine are considered as fertile grounds for exposure and transmission of the diseases to humans. In this regard, very little has been done by way of awareness creation of brucellosis 
Table 4 Knowledge of Debre Zeit and Modjo abattoirs workers about brucellosis and other zoonotic diseases by year on job, level of education, types of job, and abattoirs $(N=156)$

\begin{tabular}{|c|c|c|c|c|c|c|c|}
\hline Category & $N$ & $\begin{array}{l}\text { Brucellosis } \\
\text { (yes) N (\%) }\end{array}$ & $x^{2}$ & $P$-Value & $\begin{array}{l}\text { Zoonosis } \\
\text { (yes) N (\%) }\end{array}$ & $x^{2}$ & $P$-Value \\
\hline \multicolumn{8}{|l|}{ Level of education } \\
\hline Illiterate & 13 & $6(46.15)^{a}$ & & & $5(38.46)^{a}$ & & \\
\hline Primary & 56 & $6(28.57)^{a}$ & 11.362 & 0.010 & $21(37.50)^{a}$ & 17.120 & 0.001 \\
\hline Secondary & 65 & $32(49.23)^{b}$ & & & $38(58.46)^{\mathrm{b}}$ & & \\
\hline Post Secondary & 22 & $15(68.18)^{b}$ & & & $19(86.36)^{b}$ & & \\
\hline \multicolumn{8}{|l|}{ Types of Job } \\
\hline Animal Keepers & 23 & $8(34.78)^{a}$ & & & $12(52.17)^{\mathrm{a}}$ & & \\
\hline Slaughterers & 64 & $30(46.88)^{a}$ & & & $35(54.69)^{\mathrm{a}}$ & & \\
\hline Loaders & 33 & $11(33.33)^{a}$ & 18.888 & 0.001 & $4(42.42)^{a}$ & 13.444 & 0.009 \\
\hline Veterinarian & 12 & $12(100)^{b}$ & & & $12(100)^{b}$ & & \\
\hline Cleaners & 24 & $8(33.33)^{a}$ & & & $10(41.67)^{\mathrm{a}}$ & & \\
\hline \multicolumn{8}{|l|}{ Name of abattoirs } \\
\hline Abattoir 1 & 32 & $14(43.75)$ & & & $15(46.88)$ & & \\
\hline Abattoir 2 & 27 & $15(55.56)$ & & & $14(51.85)$ & & \\
\hline Abattoir 3 & 31 & $9(29.03)$ & 4.742 & 0.315 & $20(64.52)$ & 2.742 & 0.602 \\
\hline Abattoir 4 & 34 & $15(44.12)$ & & & $21(61.13)$ & & \\
\hline Abattoir 5 & 32 & $16(50)$ & & & $17(53.13)$ & & \\
\hline Total & 156 & $69(44.23)$ & & & $83(53.21)$ & & \\
\hline
\end{tabular}

${ }^{1}$ Within a variable, values in the same column with different letters differ significantly

and other zoonotic diseases, and as also the consumption of raw milk and meat products would lead export abattoir workers at high risk of exposure to Brucellosis and other zoonotic diseases [28].

\section{Conclusion}

This study showed the presence of seropositive abattoir workers which indicates that there are sources/foci of infection which may spread to general public. Meanwhile, the present study also revealed that working in abattoir

Table 5 Perceived predisposing factors Debre Zeit and Modjo abattoirs workers to Brucella seropositivity $(N=156)$

\begin{tabular}{llll}
\hline Risk factors & $\begin{array}{l}\text { N } \\
\text { interviewed }\end{array}$ & $\begin{array}{l}\text { Yes } \\
\text { N(\%) }\end{array}$ & No \\
\hline Use of gloves & 156 & $29(18.59)$ & $127(81.41)$ \\
Mouth cover & 156 & $21(13.46)$ & $135(86.54)$ \\
Hand wash & 156 & $152(99.36)$ & $1(0.64)$ \\
Accidental cut & 156 & $76(48.72)$ & $80(51.28)$ \\
Treatment of sore & 76 & $64(84.21)$ & $12(15.79)$ \\
Assist parturition & 156 & $14(8.97)$ & $142(91.03)$ \\
$\begin{array}{l}\text { Consumption of raw } \\
\text { meat }\end{array}$ & 156 & $109(69.87)$ & $47(30.13)$ \\
Consumption of raw & 156 & $107(68.59$ & $49(31.41)$ \\
Milk and milk products & & & \\
Own livestock & 156 & $29(18.59)$ & $127(81.41)$ \\
\hline
\end{tabular}

is a risk factor to Brucella infection. Workers in these abattoirs also do not take proper preventive measures while slaughtering and eviscerating animals and have relatively low awareness level of the diseases. This could create the risk of infection and exposure to brucellosis and other zoonotic diseases. Therefore, awareness about brucellosis and other zoonotic diseases should be created and promoted to abattoir workers. Finally, further studies should be carried out in other parts of the country not only in abattoirs, but also in general population associated with livestock to estimate the status of brucellosis and to assess also the level of awareness of the disease among occupationally exposed groups in the whole country.

\section{Abbreviations}

CFT: Compliment fixation test; d: Margin of error; $\mathrm{n}$ : The minimum sample size required for very large population; NAHDIC: National Animal Health Dagnostic and Investigation Center; P: Expected proportion of the event to be studied; RBPT: Rose Bengal plate test; $Z$ : The critical value for a given confidence interval

\section{Acknowledgement}

The authors would like to acknowledge the Akililu Lemma Institute of Pathobiology (ALIPB), Addis Ababa University and the National Animal Health Diagnostic and Investigation Center (NAHDIC) for funding this study. We are also thankful to the abattoir workers for participation in the study and also the owners and managers of the five export abattoirs for cooperation and providing necessary information. 


\section{Funding}

This study was financially supported by the Graduate Program of the Addis Ababa University.

\section{Availability of data and materials}

Please contact the corresponding author about the details of the data. Data access is subject to Graduate program library of Addis Ababa University.

\section{Authors' contributions}

AT, GT, TK conceived the study. NK, AT designed the study. AT, GT collected the data. NK, AT analyzed the data. NK, AT prepared the paper. All authors contributed to the writing of the manuscript and approved the submitted version of the manuscript.

\section{Competing interests}

The authors declare that they have no competing interest.

\section{Ethics approval and consent to participate}

Ethical clearance was obtained from Institutional Review Board (IRB) of Aklilu Lemma Institute of Pathobiology (ALIPB), Addis Ababa University. Permission was solicited from export slaughter houses. Concerning study subjects, after explaining the purposes of the study, their involvement in the study, and giving detailed explanation all about their participation, written informed consent was obtained from each participant.

\section{Consent for publication}

Not applicable.

\section{Author details}

'Akillu Lemma Institute of Pathobiology (ALIPB), Addis Ababa University (AAU), P. O. Box: 150480, Addis Ababa, Ethiopia. ${ }^{2}$ National Animal Health Diagnostic and Investigation Center (NAHDIC), Sebeta, Ethiopia.

Received: 15 April 2016 Accepted: 17 January 2017

Published online: 26 January 2017

\section{References}

1. Negash E, Shimelis S, Beyene D. Seroprevalence of small ruminant brucellosis and its public health awareness in selected sites of Dire Dawa region, Eastern Ethiopia. J Vet Med Animal Health. 2012;4:61-6.

2. WHO: Brucellosis in humans and Animals. WHO/CDS/EPR/2006. 2006;7:1-102.

3. Abubakar M, Mansoor M, Arshed MJ. Bovine brucellosis: old and new concepts with Pakistan perspective. Pak Vet J. 2012;32:147-55.

4. Ahmed MO, Elmeshri SE, Abuzweda AR, Blauo M, Abouzeed YM, Ibrahim A, Salem H, Alzwam F, Abid S, Elfahem A, Elrais A. Seroprevalence of brucellosis in animals and human populations in the western mountains region in Libya. Euro Surveill 2010; 15(30): pii: 19625

5. Swai ES, Schoonman L. The Use of Rose Bengal Plate Test to Asses Cattle Exposure to Brucella Infection in Traditional and Smallholder Dairy Production Systems of Tanga Region of Tanzania. Vet Med Int. 2010; Article ID 837950, doi:10.4061/2010/837950

6. Memish ZA, Balkhy HH. Brucellosis and International Travel: Review Article. J Travel Med. 2004:11:49-55.

7. Oking L. Emerging and re-emerging zoonotic diseases: Challenges and opportunities $72^{\text {nd }}$ General session. Paris: International Committee World Organization for Animal Health, OIE; 2004. p. 1-9.

8. Mukhtar F, Kokab F. Brucella Serology in Abattoir Workers. J Ayub Med Coll Abbottabad. 2008;20(3):57-61.

9. Moreno E, Cloeckaert A, Moriyon I. Brucella evolution and taxonomy. Vet Microbiol. 2002;90:209-27.

10. Rahman MS, Faruk MO, Her M, Kim JY, Kang SI, Jung SC. Prevalence of brucellosis in ruminants in Bangladesh. Vet Med. 2006:56(8):379-85.

11. Mk O, Skjerve E, Holstad G, Woldehiwet Z, Macmillan AP. Prevalence of antibodies to Brucella spp in cattle, sheep, goats, horses and camels in the State of Eritrea; influence of husbandry systems. Epidemiol Infect. 2002;125:447-53.

12. Madkour MM. Brucellosis: Manson's tropical diseases. UK: Elsevier; 2009. p. 1075-82.

13. Moti $Y$, Jatinder $P$, Singh $G$. Sero-epidemiological survey of human brucellosis in and around Ludhiana, India. Emerg Health Threats J. 2011;4:7361.
14. Karimi A, Alborzi A, Rasooli M, Kadivar MR, Nateghian AR. Prevalence of antibody to Brucella species in butchers, slaughterers and others. East Mediterr Health J. 2003;9:178-81.

15. Wang $X$, Feng $K$, Sun T. Epidemiological features of human brucellosis in rural areas in Shandong during 1990-996. Chung-Hua-Liu- Hsing-Ping Hsuch-Tsa-Chin. 1998:2:75-7.

16. Tolosa TF. Seroprevalence Study of Bovine Brucellosis and Its Public Health Significance in Selected Sites of Jimma Zone, Western Ethiopia. Ethiopia: Msc Thesis, Addis Ababa University, Faculty of Veterinary Medicine, Debre Zeit; 2004.

17. Kassahun A. Epidemiology of brucellosis in cattle and its seroprevalence in animal health professional in Sidama Zone, Southern Ethiopia. Ethiopia: Msc Thesis, Addis Ababa University, Faculty of Veterinary Medicine, Debre Zeit; 2004.

18. Hailemelekot M. Seroprevalence study of brucellosis in cattle and human In Bahirdar milk shed. Ethiopia: Msc Thesis, Addis Ababa University, Faculty of Veterinary Medicine, Debre Zeit; 2005.

19. Kassahun J, Yimer E, Geyid A, Abebe P, Newayeselassie B, Zewde B, Byene M, Bekele A. Sero-prevalenceof brucellosis in occupationally exposed people in Addis Ababa, Ethiopia. Ethiop Med J. 2006;44(3):245-52.

20. Haileselassie M, Kalayou S, Kyule M, Asfaha M, and Belihu K. Effect of Brucella Infection on Reproduction Conditions of Female Breeding Cattle and It's Public Health Significance in Western Tigray. Vet Med Inter, 2001; Article ID 354943, 7 pages http://dx.doi.org/10.4061/2011/354943

21. National Metrology Agency (NMA). National Metrology Authortiy. Addis Ababa, Ethiopia, 2003

22. Thrusfield M. Sampling in Veterinary Epidemiology. 3rd ed. London: Black well Science Ltd; 2007. p. 214-56.

23. Alton GG, Johanes LM, Peitz DE. Serological Methods. In: Laboratory Techniques in Brucellosis. 2nd ed. Geneva: WHO; 1975. p. 64-12.

24. Nielson K, Smith P, Yu WL, Elmgren C, Halbert G, Nicoletti P, Perez B, Conde S, Samartino L, Nicola A, Bermudez R, Renteria T. Validation of a second generation competitive enzyme Immunoassay (CELISA) for the diagnosis of brucellosis in various species of domestic animals. Vet Immunol Immunopathol. 2008;125:246-50.

25. Agasthya AS, Isloor S, Prabhudas K. Brucellosis in High Risk Group Individual. Indian J Med Microbiol. 2007;25(1):28-31.

26. Tsegay A, Tuli G, Kassa T, Kebede N. Seroprevalence and risk factors of Brucellosis in small ruminants slaughtered at Debre Ziet and Modjo export abattoirs, Ethiopia. J Infect Dev Ctries. 2015;9(4):373-80.

27. Tuli G. Seroprevalence of Brucellosis in Cattle Slaughterd at Debre Zeit Elfora and Municipality Abattoirs and Evaluation of the Risk of Infection Abattoir Workers. Addis Ababa: Msc Thesis, Addis Ababa University, Akililu Lemma Institute of Pathobiology; 2009.

28. Corbel MJ. Brucellosis in humans and animals, The World Health Organization, in collaboration with the Food and Agriculture Organization of the United Nations and the World Organization for Animal Health. Geneva: WHO Press; 2006.

\section{Submit your next manuscript to BioMed Central and we will help you at every step:}

- We accept pre-submission inquiries

- Our selector tool helps you to find the most relevant journal

- We provide round the clock customer support

- Convenient online submission

- Thorough peer review

- Inclusion in PubMed and all major indexing services

- Maximum visibility for your research

Submit your manuscript at www.biomedcentral.com/submit
Biomed Central 